\title{
DIGITALCOMMONS
}

—@WAYNESTATE-

Wayne State University

6-1-2015

\section{Influence of Changes in Political Barriers and of Geographic Distance on Kinship Inferred from Surnames and Migration Data in Olivenza (Spain) and Surrounding Portuguese Areas}

\author{
J. Román-Busto \\ Complutense University of Madrid, jmromanB@bio.ucm.es
}

\section{Recommended Citation}

Román-Busto, J., "Influence of Changes in Political Barriers and of Geographic Distance on Kinship Inferred from Surnames and Migration Data in Olivenza (Spain) and Surrounding Portuguese Areas" (2015). Human Biology Open Access Pre-Prints. Paper 81. http://digitalcommons.wayne.edu/humbiol_preprints/81 
Influence of Changes in Political Barriers and of Geographic Distance on Kinship Inferred from Surnames and Migration Data in Olivenza (Spain) and Surrounding Portuguese Areas

\section{J. Román-Busto ${ }^{1}$}

${ }^{1}$ Complutense University of Madrid, Department of Zoology and Physical Anthropology, Faculty of Biology, Madrid, Spain. E-mail: jmromanb@bio.ucm.es.

Key words: isonymy surnames, Olivenza, frontier.

Short title: Influence of Changes in Political Barriers on Kinship

Abstract The existing relationship between human populations is a function of their migratory and genetic exchange which will be inversely proportional to the distance separating them. The effect of geographic distance on population structure may be estimated by means of isonymic methods which use information on the surnames present in a territory as an approximation to the distribution of allele frequencies. The objective of this study is to analyse whether the modification in 1801 of the political border in an area surrounding the town of Olivenza, which experienced a change of sovereignty from Portugal to Spain, has had noticeable influence on the migration pattern and isolation by distance in that region. For this purpose data from marriage records of Olivenza and the neighbouring Portuguese municipalities of Alandroal, Juromenha, Elvas, Vila Boim (and Terrugem), Terena, 
Monsaraz, and Vila Viçosa were analysed. Two periods were considered in order to analyse the population structure: one prior to the change of domain (1775-1801), another after it (1802-1825), for which rates of diversity and inbreeding coefficients were determined. The results obtained show that following the border modification, the migration matrices changed differently according to sex, therefore altering the relationship between the various localities of the territory. In Olivenza inbreeding declined slightly and surnames became more heterogeneous. Moreover, following the change of domain the isolation by distance models illustrate a temporal reduction in the relative weight of geographical distance on inter-population kinship. The political border acted as a factor in population differentiation in the Iberian Peninsula (Spain and Portugal).

The region under study includes eight former Portuguese municipalities (Olivenza, Alandroal, Juromenha, Elvas, Vila Boim and Terrugem, Terena, Vila Viçosa, and Monsaraz) initially belonging to the Evora and Elvas bishoprics in the Alentejo province, close the Spanish border (Figure 1). In 1801 a political treaty changed a section of the Spanish-Portuguese border. As a consequence, Olivenza was transferred from Portugal to Spain (Román-Busto et al. 2010). The particular historic circumstances of Olivenza and the neighbouring Portuguese localities separated by the Guadiana River make this region of especial interest in relation to SpanishPortuguese border interactions (Cajal 2003). 


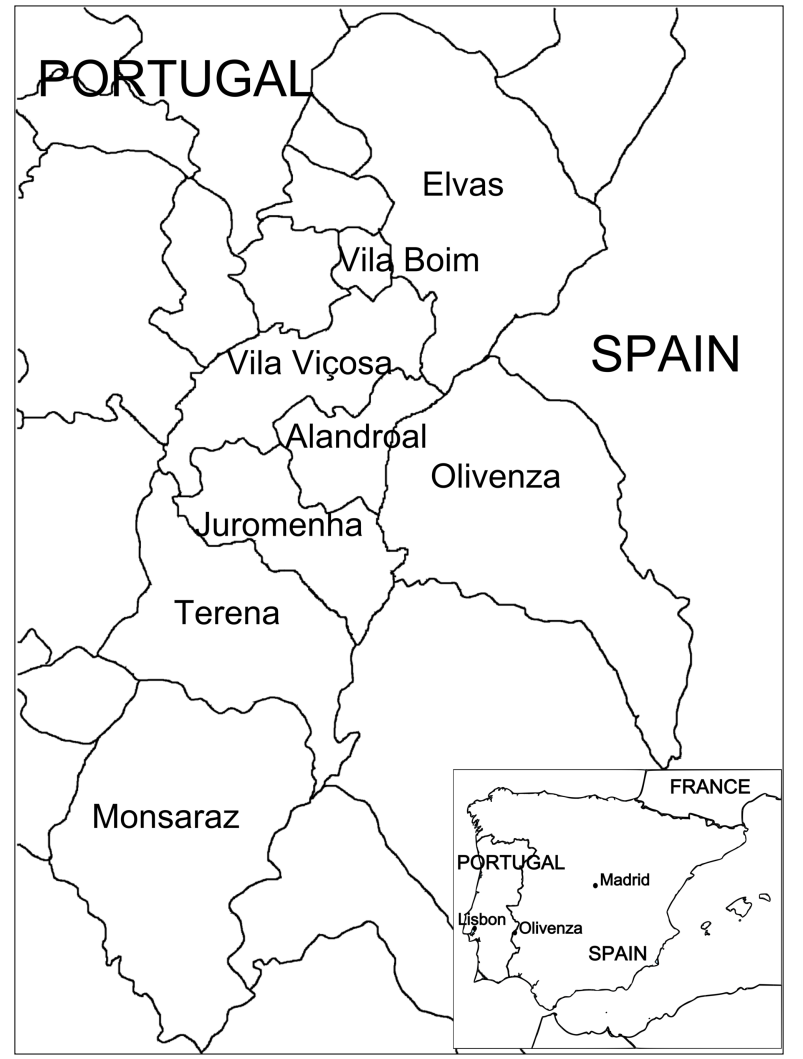

Figure 1: Location of Olivenza and the other populations studied.

The bio-demographic consequences of the change of domain in Olivenza were considered in a long term research project which has resulted in a set of previous papers (Fuster et al. 2007; Guardado-Moreira et al. 2009; Román-Busto et al. 2010; Román-Busto and Fuster 2015). The importance of political borders as factors limiting the gene flow has been previously indicated by Boldsen and Lasker (1996) with regard to the Danish-German border; by Macbeth et al., (1996) in the Cerdanya valley between France and Spain and by Abade (1992) and Eizaguirre (1994) in the north-western Spanish-Portuguese border.

According to Relethford (2012), the genetic differences between two populations are partly explained by their geographic separation: the more distant the 
populations are, the less migratory and genetic relationship will exist between them. Another factor determining a population's genetic structure is the genetic drift, mostly affected by the number of inhabitants. Migration and genetic drift have opposite effects, respectively increasing or reducing genetic diversity.

There are populations where the effect of genetic drift dominates in shortrange directional migration, while in other cases migration is the predominant factor in order to provide an interpretation of the population's genetic structure (Herrera Paz et al. 2014). Occasionally, the existence of barriers may complicate the migratory and gene flows. Examples of mechanisms which contribute to maintaining genetic isolation in some human populations include geographic and cultural barriers (Fuster et al. 2007).

Lasker and Kaplan (1985) established that a population's genetic structure may be studied by means of 'wife vs. husband' surname matrices. Numerous papers have confirmed the usefulness of surnames applied to kinship and genetic similarity models (for a complete review see Colantonio et al. 2003; and Rossi 2013).

The large sample sizes available in isonymic studies demonstrate the possibilities for using surnames to test micro-evolutionary hypotheses regarding migration, genetic drift, and admixture (Barrai et al. 2002). Isonymy also estimates the potential influence of inbreeding on the population's homozygosis, particularly where the transmission of surnames follows fixed rules (Asghar et al. 2013; Mikerezi et al. 2013)

The present paper aims to study the importance of a political frontier and its change as a barrier affecting gene flow using information from marriage records 
which provide data on surnames and places of birth and residence. Two periods of time were compared: in the first the whole set of municipalities belonged to Portugal; in the second the domain of Olivenza had been transferred to Spain. To achieve this objective the relationship between geographic distance and genetic kinship is analysed by means of kinship matrices and isolation by distance models in addition to diversity indexes and inbreeding coefficients.

\section{MATERIAL AND METHODS}

A total of 12,038 marital records from Olivenza, Alandroal, Juromenha, Elvas, Vila Boim (and Terrugem), Terena, Vila Viçosa, and Monsaraz were analysed. These records included information on place of birth and residence, bride and groom surnames, as well as those of their corresponding parents. Two periods of 25 years were considered prior to and following the change of sovereignty of Olivenza: 17751801 and 1802-1825.

The data from each municipality shown in Table 1 come from the 1801 population census (Silveira 2000). For the municipalities of Elvas, Vila Viçosa, and Monsaraz records were not transcribed for the whole set of existing parishes. In these three cases, a constant of proportionality was applied to the total census numbers, dividing the total number of residents in a municipality by the number of residents in the parishes studied. The quotient obtained was used as a weighting factor throughout the whole analysis.

Table 1: Census size per municipality and census size for the parishes selected (C.S.)

\section{Migration matrices}


Because the data came from marriage records the use of the spouses' places of birth and residence and the place of birth of their respective parents were considered the most adequate for obtaining two probabilistic matrices: a) the father's place of birth as origin (rows), and the offspring's place of birth as destination (columns). This matrix represents migration in the preceding generation; b) spouses' birthplace as origin, and husband's residence as destination. This alternative is more frequently used because it provides more available data (Relethford 2012).

Two stochastic migration matrices $\left(m_{i j}\right)$ were obtained for every period considered by dividing each cell in the matrix by the sum of the corresponding column (Imaizu et al. 1970; Jorde 1982):

1) Groom's place of birth / groom's place of residence

2) Bride's place of birth / groom's place of residence

\section{Kinship matrices}

After correlating spouses' surnames with those of their respective parents, fathers and mothers, Román et al. (2007) considered the groom's first surname and the bride's father's surname the most adequate for computing kinship matrices.

When using surnames as an estimator of genetic markers the following assumptions should be made: the monophyletic origin of each surname, minimum changes due to variation (mutation), and equal migration rates for males and females (Fuster 1982). Because of the relatively small size of the region under study, bias due to polyphyletic surnames is expected to have been reduced. Contrarily, spelling variations may have been important in Olivenza where after the change of 
sovereignty some Portuguese surnames adopted Spanish spelling. The noncompliance of the above assumptions diminishes the reliability of estimated kinship. In spite of that, the relative kinship values obtained are useful (Relethford, 1988). In the present paper grooms' and brides' surnames were analysed together, thus maximising each population sample size (Esparza 2004).

Intra-population kinship was calculated on the basis of Morton's a priori kinship matrix, following Relethford (1988):

$$
\Phi_{i i}=I_{i i} / 4
$$

being $I_{i i}=\frac{\sum_{i} n_{i k}\left(n_{i k}-1\right)}{N_{i}\left(N_{i k}-1\right)}$

where $n_{i k}$ is the number of individuals in population ' $i$ ' taking surname $k, N_{i}$ is the total number of surnames in population ' $i$ '. The summation refers to the whole set of surnames.

Inter-population kinship was calculated as:

$$
\Phi_{i j}=I_{i j} / 4
$$

being $I_{i j}=\frac{\sum n_{i k} n_{j k}}{N_{i} N_{j}}$

where $\boldsymbol{n}_{i k}$ and $\boldsymbol{n}_{j k}$ indicate individuals with surname $k$ in populations $i$ and $j$ respectively; $N_{i}$ and $N_{j}$ represent the total number of inhabitants in populations $i$ and $j$, estimated from the summation of the whole set of surnames. 
The genetic distance between populations, $d^{2}$, was estimated according to Relethford (1988), based on Harpending and Jenkins (1973) and Morton (1975). Thus:

$$
d^{2}=I_{i i}+I_{j j}-2 I_{i j}
$$

The genetic distance estimated from random isonymy was represented by means of multidimensional scaling analysis (MDS), which permits the graphic emphasis of the topological relationship among the populations studied (Caravello and Tasso 2002).

A matrix of geographic inter-population distance was developed considering the UTM (Universal Transverse Mercator) coordinates of the capital of each municipality.

The migration $\left(m_{i j}\right)$, Relethford's genetic distance $\left(d^{2}\right)$, Morton's a priori kinship, and geographic distance matrices were correlated using the Mantel (1967) test.

\section{Isolation by distance}

The correlation between the isonymic relationships between populations $i$ and $j$ with their geographic distance allows the estimation of isolation by distance parameters (Malécot 1948). The non-weighted mean local kinship 'a' and the rate of decrease in kinship with geographic distance ' $b$ ' (Relethford and Brennan, 1982) were obtained for each period by means of non-linear regression of a priori kinship on the geographic distance. The former Malécot (1948) formula was simplified for finite populations at short distances according to Imaizumi et al. (1970): 


$$
\Phi_{i j}=a e^{-b d}
$$

The use here of an a priori kinship matrix to estimate ' $a$ ' and ' $b$ ' is appropriate (Relethford 1988) since this matrix is not based on previous knowledge of the regional random isonymy.

The impact of census size on inter-population kinship was estimated by applying the Dahlberg (1948) non-linear regression model, following Santos et al. (2005).

$$
\Phi_{i i}=a\left(\frac{1}{N_{i}}\right)^{b}
$$

Where $a$ and $b$ are the constants of the regression model.

\section{Inbreeding and surname diversity}

To characterise populations and analyse their inter-period differences the total inbreeding $\left(F_{t}\right)$ and its two components—random $\left(F_{r}\right)$ and non-random $\left(F_{n}\right)$-were calculated following Crow and Mange (1965) and Crow (1980).

Information on the effects of genetic drift or gene flow on the differences among populations from the area analysed was estimated from the proportion of the total variation in the region studied, explained by the variation among subgroups (Relethford 2012):

Fst = variation between groups / total variation 
The comparison of Fst in the first period with that of the second provides information on the importance of genetic drift and gene flow after the change of sovereignty.

As an indicator of the diversity of surnames the Shannon's index, $H$, was determined (Shannon and Weaver 1949). This index is independent of sample size and takes into account the number of surnames which are different as well as the homogeneity of their distribution. An isolated community would show a low diversity of surnames, thus resembling a genetic isolate. On the contrary, a population with high values would have maintained considerable gene exchange with other regions (Esparza 2004). The $H$ diversity index was calculated as:

$$
H_{i}=-\sum_{i} p_{i} \operatorname{Ln} p_{i}
$$

where $p_{i}$ is the probability of the ith surname in each population and period.

The Mantel, Pearson, and Spearman correlations, as well as the linear and non-linear regressions were computed with XLSTAT-Pro 2014.2.

\section{RESULTS AND DISCUSSION}

\section{Migration matrices}

Male and female migration matrices based on place of birth/residence are correlated both in the first $(R=0.691, p<0.001)$ and in the second period $(R=0.417$, $p<0.01)$. In the following analysis marital matrices were used as they provide larger sample numbers.

Table 2 shows correlations between migration and geographic distance matrices. In the first period the correlation coefficient for males is $R=-0.441(p<$ 
$0.001)$; in the second, $R=-0.285(p<0.05)$. For females the corresponding values are $R=-0.549(p<0.001)$ and $R=-0.588(p<0.001)$. For males, although correlation remains significant, from the first to the second period a lower coefficient is observed. In females correlation coefficients remain elevated due to their lower marital mobility (Fuster 1982; Guardado Moreira et al. 2009).

Table 2: Mantel correlations among male $\left(m_{\mathrm{ij}} \mathrm{M}\right)$ and female $\left(\mathrm{m}_{\mathrm{ij}} \mathrm{F}\right)$ migration matrices; genetic distance $\left(d^{2}\right)$; kinship coefficients $\left(\varnothing_{i j}\right)$, and geographic distances $(G d)$. Bottom left: period 1 (1775-1801); top right: period 2 (1802-1825).

\section{Kinship matrices}

Genetic distances calculated from random isonymy are represented in Figure 2 for the first period. It is observed that Olivenza, as well as Monsaraz and Vila Viçosa were initially in a peripheral position with regard to the rest of the populations.

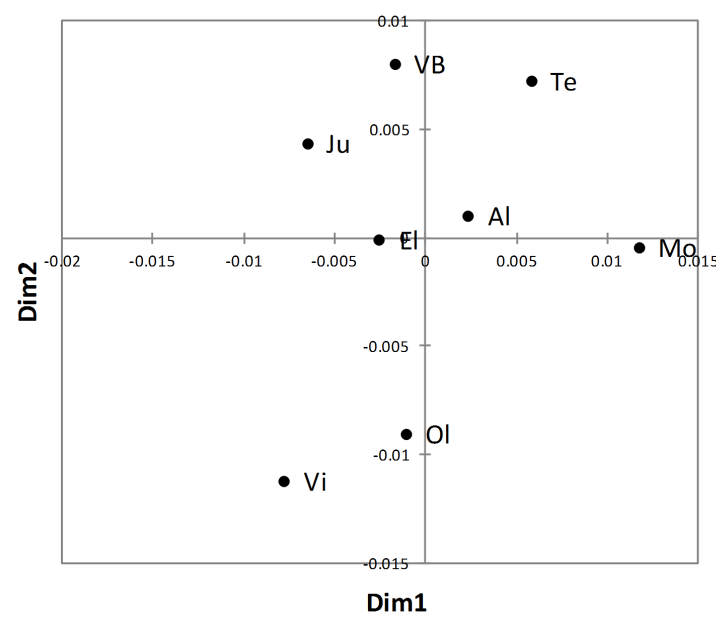

Figure 2: Multidimensional scaling analysis plot representing genetic distance in the period $1775-1801$ based on the random isonymy matrix for the localities studied: 
Olivenza (OI), Alandroal (Al), Juromenha (Ju), Elvas (El), Vila Boim and Terrugem (VB), Terena (Te), Vila Viçosa (Vi) and Monsaraz (Mo).

This result is reflected by the values of the Mantel test shown in Table 2, where non-significant correlations between genetic and geographic distances were found. Nor was significance proved by comparing genetic kinship matrices with regard to the male-female migration matrices. Non-significant correlations are expected in relatively small regions in which important geographic barriers are absent. The above results indicate that the populations studied are genetically more homogeneous than expected considering the kilometric distance between them (Santos et al. 2005), which is greatest between Vila Boim and Monsaraz (46 Km). Therefore, a certain similarity exists in the set of surnames studied.

Correlation between the first-second periods' $\varnothing_{\mathrm{ij}}$ matrices (right column in Table 2$)$ is $R=0.737(p<0.0001)$. In contrast to the inter-population kinship matrices, no inter-period correlation has been found for the genetic distance matrices. This is due to the fact that the index of genetic distance $\left(d^{2}\right)$ includes in its calculation the values of inter-population kinship. As observed in Table 3, $F_{t}$ does not increase from the first to the second period in all of the populations considered.

\section{Isolation by distance, kinship, and population size}

The effect of geographic distance on the populations' genetic similarity was estimated by means of two types of regressions. When applying the Malecot (1948) isolation by distance model for the first period, the coefficient of determination obtained after a nonlinear regression analysis indicates that only $12 \%$ of kinship variability is explained by kilometric distance. Although significant, this is a low value, 
which is consistent with the correlations obtained between kinship from surnames and geographic distance. In the second period, the coefficient of determination remained significant despite lowering the explained variation to $2 \%$. According to the isolation by distance model, in the first period the parameter 'a' was 0.010 and 'b' was 0.428 . The corresponding values for the second period are 0.007 and 0.196 . The limitation of the comparison of the isolation by distance parameters is complicated by the size and definition of the populations studied (Relethford, 2012), the values found here are within the range typical of European continental regions (Abade 1992) and intermediate in terms of those reported by Fuster (1982) in Northern Spain and by Abade (1992) in Northern Portugal.

The $\varnothing_{\mathrm{ii}}$ values are conditioned by the population size. The smaller a population is, the greater the probability of significant genetic drift will be. Because of this, to determine the genetic drift effect due to isolation, control is necessary according to population size (Abade 1992).

The results of the Dahlberg (1948) non-linear model are shown in Figure 3 for the first period. The coefficient of determination was significant: $R^{2}=0.483(a=0.05$; $b=0.205)$. In the second period the value decreased but remained significant: $R^{2}=$ $0.285(a=0.04 ; b=0.198)$. 


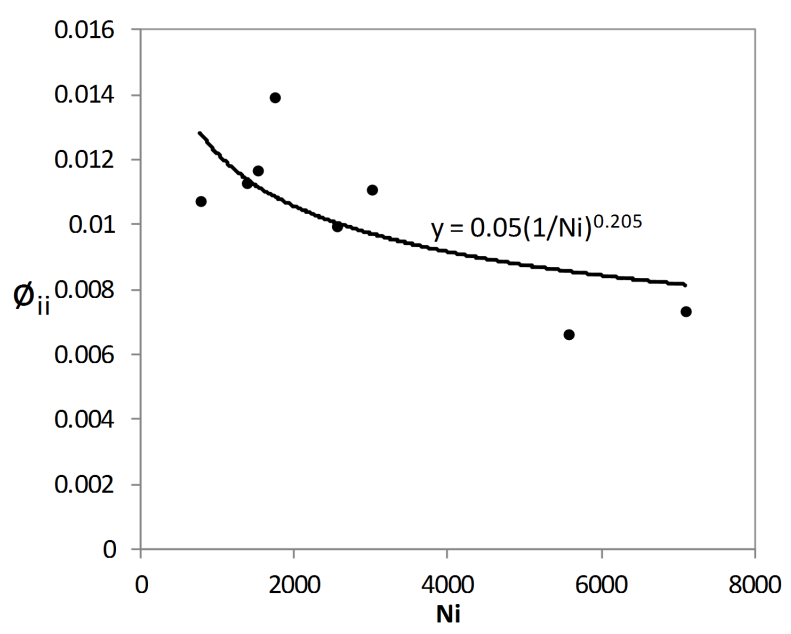

Figure 3: Dahlberg non-linear correlation model between $N_{i}$ and $\emptyset_{\mathrm{ii}}$. Period $1775-$ 1801.

\section{Inbreeding and diversity}

The values of diversity and inbreeding complement the previous analyses by providing information on the contribution of random and cultural components to total inbreeding. The comparison of Tables 1 and 3 show that large $(\mathrm{N})$ populations, such as Olivenza and Elvas, present greater diversity in surnames $(H)$ in both periods. $H$ and $\mathrm{N}$ have a significant Spearman's rho correlation in the first period $r=0.762(p<$ $0.05)$, but not in the second $(r=0.643)$. In contrast, total inbreeding is higher in Alandroal, Juromenha, and Vila Viçosa, for the 1775-1801 period, with the first two localities having a small census size. The variation of values in the second period was more intense in the municipalities where the effect of the border change was greater. In Alandroal, Juromenha, Elvas, Vila Boim, and Terena negative nonrandom coefficients $(F n)$ were found in both periods. For other ranges of years prior to and after the two defined here, Román-Busto and Fuster (2015) reported similar values for Fn in Olivenza. Despite the fact that the temporal range in that study was 
different, alternation of positive and negative Fn values was observed with a yearly growth tendency (Román et al. 2009). In the present analysis, the inter-periods comparison shows significant Spearman's correlation $(p<0.05)$ for the random $(F r)$ and non-random components $(r=0.738 ; r=0.810$ for $\mathrm{Fr}$ and $\mathrm{Fn}$, respectively). $\mathrm{Fr}$ correlates negatively with the census size in the first period $(r=-0.763 ; p<0.05)$ but not in the second.

Table 3: Components of inbreeding by isonymy $\left(X 10^{3}\right): F_{r}$ (random component), $F_{n}$ (non-random component), $F_{t}$ (total inbreeding); $H$ (Shannon's diversity index).

Surname diversity increased in all localities from the first to the second period, especially in Olivenza, Alandroal, Juromenha, and Elvas. In Olivenza, since the change of domain, new surnames were incorporated by mixed marriages with Spaniards. This coincides, according to Román-Busto et al. (2010), with a reduction in the frequency of the five most common surnames from $40 \%$ in $1750-1760$ to $21 \%$ in 1841-1850. At the same time Portuguese residents in Olivenza moved to the neighbouring localities in Portugal, where new surnames were introduced. As a consequence of these population movements, total inbreeding could have reduced from one period to the next in most localities. Exceptions are Monsaraz and Terena which do not border Olivenza and therefore the dynamic of their population may have been less affected by the change of domain. On the other hand, Alandroal, Juromenha, and Elvas, located close to Olivenza, reduced inbreeding noticeably.

The inbreeding coefficients obtained are similar to those reported for other nearby regions such as the municipalities along the Miño River (Northern Portugal) 
studied by Eizaguirre (1994), as well as some areas in the northeast of the SpanishPortuguese border (Abade 1992; Alvarez et al. 2010). But coefficients are lower than those reported for areas of Castilla-León (Spain) such as the Gredos Mountain range (Fuster et al. 1996) and La Cabrera, for which Blanco-Villegas et al. (2004) reported some of the highest values for this country. Most of these areas are characterised by being rural and in them $F_{n}$ increased the smaller the number of inhabitants of each locality was.

With Olivenza being a military garrison, the negative $F_{n}$ may be explained by lack of interest in consanguineous unions (Román-Busto et al. 2010; Román-Busto and Fuster 2015). An equivalent lack of preference for these types of marriages was extended to the nearby municipalities of Alandroal, Juromenha, Elvas, Terena, and Vila Boim. However, Blanco-Villegas et al. (2004) and Alvarez et al. (2010) indicate that when $F_{n}$ takes values close to cero or negative in a population, and $F_{t}$ and $F_{r}$ show similar magnitude, this would be indicative of such a population constituting a reproductive unit. The opposite reflects reproductive substructures in each population. In the region under study, the municipalities would be the reproductive unit given the ease of movement among the parishes (inferior territorial unit) that form them. After the combination of data from the 8 municipalities studied (Table 3 , bottom), $F_{n}$ in each municipality is not always greater than the total $F_{n}$. For this reason, according to Blanco-Villegas et al. (2004), the Wahlund effect resulting in a population composed of various isolated reproductive units should be discarded.

The variation between groups / total variation $\left(F_{s t}\right)$ declined from the first period $\left(8.407 \times 10^{-3}\right)$ to the second $\left(7.01 \times 10^{-3}\right)$ thus demonstrating intermediate levels of micro-differentiation. These values are lower than those found in a Galician 
region (Fuster 1986) where isolation was elevated, but higher than those reported by Alvarez et al. (2010). It is necessary to add that $F_{\text {st }}$ heterogeneity may also reflect differences in population size.

Analysing all of the results together a variation in the migration matrices is demonstrated after the border modification, affecting Olivenza. The change did not have an immediate effect on the kinship matrices, which remained similar prior to and after the change of sovereignty (Table 2). Migration matrices and geographic distance matrices show significant correlations, but with smaller correlation coefficients than found by Fuster (1986) in Northern Spain, where the parishes studied were $9 \mathrm{~km}$ apart at most. As the surface of the territory under study enlarges, the effect of kilometric distance on the migration matrices may decrease (Relethford 2012). The Guadiana River, which could have acted as a barrier between Olivenza and the other Portuguese municipalities, apparently has not conditioned population exchange as occurred with other rivers in different Spanish regions (Eizaguirre 1994; Esparza et al. 2006).

The use of observed migration and census sizes permits the prediction of the genetic variation patterns expected according to the balance between gene flow and genetic drift. In Olivenza, as in the other municipalities studied, kinship does not correlate with kilometric distance as expected according to the Malécot (1950) model. Concordance between kinship, geographic distance, and migration matrices was not probable partly because the hypothesis of equivalence of genes and surnames is distorted by polyphyletic surnames. Moreover, migration matrices reflect a period of time shorter than kinship matrices which mirror the accumulation of surnames across various generations (Raspe and Lasker 1980; Fuster 1986). 
The more isolated populations are, the greater the influence of geographic distance on population structure (Relethford 1982; Fuster 1986). In the present analysis isolation by distance indicates that geographic distance is inversely proportional to kinship, mainly in the first period. This shows the existence of new factors, such as the border change, which have conditioned gene distribution in the population.

The non-linear Dahlberg (1948) model shows that in Olivenza and the surrounding municipalities, inter-population kinship in both periods correlates with the population size, although this correlation reduced after the border change. The Spearman correlation of random inbreeding with population size becomes nonsignificant after this change. Although isolation by distance depends on the exchange of individuals among neighbouring localities, usually it is conditioned by their spatial separation; moreover, the migratory rates may modify over time (Relethord 2010). In some populations a selective migratory pattern involving relatives' lines has been found, with greater changes of migration to the localities where ancestors came from or where relatives reside. This fact, frequent for long-distance migration, is also detected for short distance migration (Harpending 1974). Although the migratory movements detected in the region studied are mostly explained by geographic distance, their patterns prior to and after the border change should be attributed to other factors which could be compatible with selective migration. Considering that part of the population was constituted by members of the army, many individuals may have moved back to their places of origin.

In the border territory studied, a political event affecting the border had consequences on the population structure of Olivenza and the surrounding 
Portuguese municipalities, by modifying the migratory flows and the pre-existing isolation by distance model. The initial demographic instability recovered equilibrium after a certain period of time when the new border became, with regard to population exchange, a rather permeable limit dependent on the characteristics and socioeconomic importance of each municipality (Román-Busto et al. 2010, 2013).

For the Danish-German border, Boldsen y Lasker (1996) reported a certain heterogeneity of surnames in the neighbouring regions, which was attributed more to the particular history of surnames than to genetic variability. The coincidence of the geographic barrier (Pyrenees mountain range) and the political border between France and Spain made it difficult to differentiate between the influence of the two (Macbeth et al. 1996). In northern Portugal, Abade (1992) and Eizaguirre (1994) gave more importance to geography and to the rivers that acted as borders than to the political boundaries.

From the results obtained, it is concluded that the modification of the frontier surrounding Olivenza has had an influence not only on the structure of this population but also on others that remained under Portuguese sovereignty. The migration matrix and isolation by distance models were upset as a consequence of that historical event. In terms of the migration matrices, although maintaining a similar pattern from the first to the second period, the correlation with those of preceding generations disappeared after the change of domain. The correlation between male and female matrices also reduced; that is, following the change of domain differential migration by sex was detected. With regard to geographic distance, the negative correlation with the migration matrices increased slightly, while in males the decrease was noteworthy. Concerning kinship, an initial situation 
reflecting a certain similarity and homogeneity of surnames in the region is transformed in the second period into another situation with a light reduction of $F_{\text {st. }}$ The absence of micro-differentiation increase following the change of domain is attributed to the transfer of populations from Olivenza to other nearby municipalities. Accordingly, the kinship matrices do not demonstrate the existence of barriers limiting movement from Olivenza to the neighbouring localities, while a reduction of inbreeding is observed from one period to the next. The isolation by distance models indicate a small impact of geographic distance on kinship, which despite reducing after 1801 retains values that are within the range of European continental populations.

In summary, although political borders only partially restrict intermarriage due to their permeability, which is determined by historical and cultural factors, the existence of this type of barriers should be taken into account when explaining the genetic differentiation of human populations.

Acknowledgements This work was supported by the Spanish Ministry of Education and Science (project reference CGL2004-00928/BOS). Thanks to the Arquivo Distrital de Évora, to the Arquivo Histórico da Câmara Municipal de Elvas, and to the Family History Centre of the Church of Jesus Christ of the Latter-Day Saints (Madrid: Pablo Iglesias Avenue) for allowing data collection, and to Raquel Palomeque Camacho for her collaboration in the transcription of data. $<$ ACK>

Received 9 July 2015; revision accepted for publication 24 September 2015. 


\section{Literature Cited}

Abade, A. 1992. A população inexistente: Estrutura demográfica e genética da população da Lombada, Bragança.

Alvarez, L., C. Mendoza, R. M. Nogués et al. 2010. Biodemographic and genetic structure of Zamora Province (Spain): Insights from surname analysis. Hum. Ecol. 38:831-839.

Asghar, M., B. Murry, and K. N. Saraswathy. 2013. Isonymy and repeated pairs of surnames among the Muslims of Manipur, India. Homo. 64:312-316.

Barrai, I., A. Rodríguez-Larralde, F. Manni et al. 2002. Isonymy and isolation by distance in the Netherlands. Hum. Biol. 74:263-283.

Blanco-Villegas, M. J., A. Boattini, H. R. Otero et al. 2004. Inbreeding patterns in La Cabrera, Spain: dispensations, multiple consanguinity analysis, and isonymy. Hum. Biol. 76:191-210.

Boldsen, J., and G. W. Lasker. 1996. Relationship of people across an international border based on an isonymy analysis across the German-Danish frontier. J. Biosoc. Sci. 28:177-183.

Cajal, M. 2003. Ceuta, Melilla, Olivenza y Gibraltar: ¿dónde acaba España? Siglo XXI de España Editores S.A. Madrid.

Caravello, G. U., and M. Tasso. 2002. Use of surnames for a demo-ecological analysis: A study in southwest Sardinia. Am. J. Hum. Biol. 14:391-397. 
Colantonio, S., G. W. Lasker, B. A. Kaplan et al. 2003. Use of surname models in human population biology: A review of recent developments. Hum. Biol. 75:785-807.

Crow, J. F., and A. P. Mange. 1965. Measurement of inbreeding from the frequency of marriages between persons of the same surname. Eugen. Q. 12:199-203.

Crow, J. F. 1980. The estimation of inbreeding from isonymy. Hum. Biol. 52:1-14.

Dahlberg, G. 1948. Mathematical Methods for Population Genetics. Basle: Interscience Publishers.

Eizaguirre, M. 1994. Down to the River. Master of Science Thesis. Department of Anthropology, University of Durham.

Esparza, M., C. García-Moro and M. Hernández, M. 2006. Genetic relationships between parishes in the Ebro delta region (Spain) as estimated by migration matrix and surnames. Hum. Biol. 78:647-662.

Esparza, M. 2004. Biodemografia del delta de l'Ebre: Estructura matrimonial. Doctoral dissertation, Tesis doctoral. Universitat de Barcelona.

Fuster, V., M. S. Mesa, A. Jiménez et al. 1996. Surname distribution and population characteristics of two Gredos valleys (Spain). Riv. Antropol. 74:105-114.

Fuster, V., J. Román, M. J. Guardado et al. 2007. Influence of Spanish-Portuguese border changes in 1801 on the mating pattern of Olivenza. New Perspectives and Problems in Anthropology. Newcastle upon Tyne: Cambridge Scholars Publishing.

Fuster, V. 1982. Estructura antropogenética de la población de nueve parroquias del municipio de Los Nogales, Lugo (1871-1977). Madrid, Spain: Editorial de la Universidad Complutense. 
Guardado-Moreira, M. J., J. Román-Busto, S. Colantonio et al. 2009. Influência das alterações da fronteira luso-espanhola nos factores exógenos de reprodução económica, social e cultural: O caso de Olivença. População e Sociedade. 17:85.

Harpending, H. and T. Jenkins. 1973. Genetic distance among southern African populations. In Methods and Theories of Anthropological Genetics, M. Crawford and P. Workman, eds. Albuquerque: University of New Mexico Press, 177.

Harpending, H. 1974. Genetic structure of small populations. Annu. Rev. Anthropol. 3:229-243.

Herrera Paz, E. F., C. Scapoli, E. Mamolini et al. 2014. Surnames in Honduras: A study of the population of Honduras through isonymy. Ann. Hum. Genet. 78:165-177.

Imaizumi, Y., N. E. Morton, and D. E. Harris. 1970. Isolation by distance in artificial populations. Genetics 66:569.

Jorde, L. B. 1982. The genetic structure of the Utah Mormons: Migration analysis. Hum. Biol. 54:583-597.

Lasker, G. W., and B. A. Kaplan. 1985. Surnames and genetic structure: Repetition of the same pairs of names of married couples, a measure of subdivision of the population. Hum. Biol. 57:431-440.

Macbeth, M., M. Salvat, M. Vigo et al. 1996. Cerdanya: Mountain valley, genetic highway. Ann. Hum. Biol. 23:41-62.

Malécot, G. 1948. Mathematics of heredity. Les mathematiques de l'heredite. Paris, France. 
Malécot, G. 1950. Quelques schémas probabilistes sur la variabilité des populations naturelles. Annales de l'Université de Lyon A. 13:37-60.

Mantel, N. 1967. The detection of disease clustering and a generalized regression approach. Cancer Res. 27:209-220.

Mikerezi, I., E. Xhina, E, C. Scapoli et al. 2013. Surnames in Albania: A study of the population of Albania through isonymy. Ann. Hum. Genet. 77:232-243.

Morton, N. E. 1975. Kinship, information and biological distance. Theor. Popul. Bio. $7: 246-255$.

Raspe, P. D., and G. W. Lasker. 1980. The structure of the human population of the Isles of Scilly: Inferences from surnames and birthplaces listed in census and marriage records. Ann. Hum. Biol. 7:401-410.

Relethford, J. 1988. Estimation of kinship and genetic distance from surnames. Hum. Biol. 60:475-492.

Relethford, J. H., and E. R. Brennan. 1982. Temporal trends in isolation by distance on Sanday, Orkney Islands. Hum. Biol. 54:315-327.

Relethford, J. H. 2012. Models of Natural Selection, in Human Population Genetics. Hoboken, NJ: John Wiley \& Sons, Inc.

Román, J., S. Colantonio, M. J. Blanco et al. 2009. Structure of the Olivenza population by analysis of repeated pairs of surnames in Spanish and Portuguese lineages. Ann. Hum. Biol. 36:653. 
Román, J., M. J. G. Moreira, P. Zuluaga et al. 2007. Estudios de isonimia en Portugal: Consideraciones metodológicas. Antropo. 14:47.

Román-Busto, J., and V. Fuster. 2015. Secular trends in the relationship between surnames in a population: Study of a border town. Homo. In Press. Corrected proofs available online 21 January 2015.

Román-Busto, J, V. Fuster, S. Colantonio et al. 2010. Mate choice in Olivenza: Influence of border change on Spanish-Portuguese lineages. J. Biosoc. Sci. 42:129140.

Román-Busto, J., V. Fuster, and S. E. Colantonio. 2012. Portuguese migration to the Canary Islands: an analysis based on surnames. Anthropol. Anz. 69:243-253.

Román-Busto, J., M. Tasso, G. Caravello et al. 2013. Genetics of population exchange along the historical Portuguese-Spanish border. J. Biosoc. Sci. 45:79-93.

Rossi, P. 2013. Surname distribution in population genetics and in statistical physics. Phys. Life. Rev. 10:395-415.

Santos, C., A. Abade, J. Cantons et al. 2005. Genetic structure of Flores island (Azores, Portugal) in the 19th century and in the present day: evidence from surname analysis. Hum. Biol. 77:317-341.

Shannon, C. E., and W. Weaver. 1949. The Mathematical Theory of Communication. Urbana: University of Illinois Press.

Silveira, L. N. 2000. Os Recenseamentos da População Portuguesa de 1801 e 1849. Edição Crítica, Lisboa, Instituto Nacional de Estatística. 
Table 1: Census size per municipality and census size for the parishes selected (C.S.)

\begin{tabular}{l|cccc} 
Municipality & Total & C.S. & \% Selected & Weight \\
\hline Olivenza & $5569^{*}$ & 5569 & 100 & \\
Alandroal & 1519 & 1519 & 100 & \\
Juromenha & 774 & 774 & 100 & \\
Elvas & 13274 & 7094 & 53.4 & 1.87 \\
Vila Boim & 1377 & 1377 & 100 & \\
Terena & 1740 & 1740 & 100 & \\
Vila Viçosa & 3767 & 3006 & 79.8 & 1.25 \\
Monsaraz & 4913 & 2551 & 51.9 & 1.92
\end{tabular}

* Until 1842 the town of Olivenza also included the parish of St. Jorge de Alor, which would bring the census to 6,737 inhabitants. But due to its distance of $6 \mathrm{~km}$ from the capital of the municipality and its subsequent segregation from Olivenza, it has not been considered in the analysis. 
Table 2: Mantel correlations among male $\left(m_{\mathrm{ij}} \mathrm{M}\right)$ and female $\left(\mathrm{m}_{\mathrm{ij}} \mathrm{F}\right)$ migration matrices; genetic distance $\left(d^{2}\right)$; kinship coefficients $\left(\emptyset_{i j}\right)$, and geographic distances (Gd). Bottom left: period 1 (1775-1801); top right: period 2 (1802-1825).

Type of matrix

\begin{tabular}{|c|c|c|c|c|c|c|}
\hline & $m_{i j} M$ & $m_{i j} F$ & $d^{2}$ & $\boldsymbol{\sigma}_{\mathrm{ij}}$ & Gd & $\begin{array}{l}\text { period } \\
\text { correlation }\end{array}$ \\
\hline $\mathbf{m}_{\mathrm{ij}} \mathbf{M}$ & & $0.417^{*}$ & 0.168 & -0.231 & $-0.285^{*}$ & $0.533^{* *}$ \\
\hline$m_{\mathrm{ij}} F$ & $0.691^{* *}$ & & 0.259 & -0.024 & $-0.588^{* *}$ & $0.590^{* *}$ \\
\hline$d^{2}$ & -0.012 & -0.104 & & -0.299 & -0.357 & -0.245 \\
\hline$\varnothing_{i j}$ & 0.205 & 0.114 & -0.245 & & -0.100 & $0.737^{* *}$ \\
\hline Gd & $-0.441^{* *}$ & $-0.549^{* *}$ & 0.265 & -0.356 & & \\
\hline${ }^{* *}$ sig & nificant $p$ & $<0.001$ & ${ }^{*} p<c$ & 0.05 & & \\
\hline
\end{tabular}


Table 3: Components of inbreeding by isonymy $\left(\mathrm{X} \mathrm{10}^{3}\right): F_{r}$ (random component), $F_{n}$ (non-random component), $F_{t}$ (total inbreeding); $H$ (Shannon's diversity index).

\section{PERIOD}

\begin{tabular}{l|llll|llll|}
\multicolumn{7}{c}{} & \multicolumn{5}{c}{$1775-1801$} \\
\cline { 2 - 8 } Municipality & $\mathbf{F}_{\mathbf{r}}$ & $\mathbf{F}_{\mathbf{n}}$ & $\mathbf{F}_{\mathbf{t}}$ & $\mathbf{H}$ & $\mathbf{F}_{\mathbf{r}}$ & $\mathbf{F}_{\mathbf{n}}$ & $\mathbf{F}_{\mathbf{t}}$ & $\mathbf{H}$ \\
\hline Olivenza & 4.604 & 1.268 & 5.865 & 4.505 & 4.202 & 0.118 & 4.32 & 4.649 \\
Alandroal & 13.457 & -2.359 & 11.129 & 3.344 & 9.526 & -4.46 & 5.108 & 3.488 \\
Juromenha & 10.901 & -1.305 & 9.61 & 3.509 & 4.878 & -3.275 & 1.619 & 3.636 \\
Elvas & 5.296 & -1.556 & 3.748 & 4.05 & 3.554 & -1.922 & 1.639 & 4.389 \\
Vila Boim & 9.324 & -1.24 & 8.095 & 3.657 & 6.899 & -1.185 & 5.723 & 3.825 \\
Terena & 12.394 & -4.922 & 7.533 & 3.351 & 11.368 & -3.089 & 8.314 & 3.394 \\
Vila Viçosa & 7.739 & 3.613 & 11.324 & 3.908 & 7.515 & 1.603 & 9.106 & 3.918 \\
Monsaraz & 8.366 & 0.305 & 8.668 & 3.664 & 8.599 & 2.243 & 10.823 & 3.645 \\
Total & 6.345 & 0.894 & 7.234 & ----- & 4.694 & 0.886 & 7.234 & -----
\end{tabular}

